\title{
Aplikasi Insektisida Nabati Berbahan Utama Tumbuhan Rawa Dalam Mengendalikan Hama Utama Padi Di Lahan Rawa Pasang Surut
}

\author{
Application of Biological Insecticide Made from Swamp Plants in Controlling Main Rice \\ Pests in Tidal Swamp Land
}

\section{Syaiful Asikin, Yuli Lestari}

Balai Penelitian Pertanian Lahan Rawa, Jl. Kebun Karet, Lok Tabat Kotak Pos 31 Banjarbaru 70712 Indonesia

*E-mail Penulis Korespondensi: syaifulasikin1958@gmail.com

Tanggal submisi: 25 Mei 2002; Tanggal penerimaan: 28 Juni 2020

\begin{abstract}
Based on integrated pest control, the use of toxic chemicals or chemical pesticides/insecticides is the last alternative if other components are no longer able to control, then pesticides/insecticides can be used. Currently, plantbased insecticides are being developed in controlling plant pests. Unwise and continuous use of chemical pesticides/insecticides will cause environmental pollution problems that result in pest outbreaks, pest resistance, and resurgence, ridding of non-targeted pests and natural enemies of plant pests and bad effects on consumers and pets. About 350-500 species of plants have the potentials to become sources of plant-based insecticides, from that number around 90-100 species of swamp plants have the potentials to be used as biological insecticides in controlling rice and vegetable/horticulture pests. Some of the plant species that extracts were used in this study were 'jingah', 'tapak liman', 'simpur' and 'kamandrah'. This study was arranged in an experiment using a randomized block design (RBD) with 5 replications. The treatments given included extracts of 4 types of swamp plants plus 3 control treatments, namely control 1 (without pest control), control 2 (BGA plant-based insecticide treatment), and control 3 ('Dimehipo' chemical insecticide). From the results of the study it could be concluded that extracts for 'jingah', 'tapak liman', 'simpur' and 'kamandrah' were effective in controlling the main rice pests in the tidal swamp land. As for the yield of dried grain harvest in the swamp, plant extracts 4.54-4.62 and control of chemical insecticides $4.63 \mathrm{t} / \mathrm{ha}$, BGA biological insecticide. For convenience for use, Jingahextracts need to be considered because this jingah plant extract can cause allergies and itching when exposed to the skin and is very disturbing for the user.
\end{abstract}

Keywords: application, rice pest, tidal swamp, vegetable insecticide

\section{ABSTRAK}

Berdasarkan pengendalian hama terpadu, penggunaan bahan kimia beracun atau pestisida/insektisida kimiawi merupakan alternatif terakhir apabila komponen lainnya tidak mampu lagi, baru pestisida/insektisida dapat digunakan. Bahkan sekarang ini mulai dikembangkan pestisida/insektisida nabati dalam mengendalikan hama tanaman. Penggunaan pestisida/insektisida kimiawi yang kurang bijak dan terus-menerus akan menyebabkan masalah pencemaran lingkungan yang berakibat terjadinya ledakan hama, terjadinya resistensi dan resurgensi hama, terbunuhnya hama bukan sasaran dan musuh alami hama tanaman, serta pengaruh buruk bagi konsumen dan hewan peliharaan. Di lahan rawa ditemukan sekitar 350-500 jenis tumbuhan/tanaman yang berpotensi sebagai insektisida nabati, dari jumlah tersebut sekitar 90-100 jenis tumbuhan rawa berpotensi sebagai bahan pembuatan insektisida nabati dalam mengendalikan hama padi, hama sayuran/hortikultura. Beberapa jenis tumbuhan tersebut yang ekstraknya digunakan pada penelitian ini adalah jingah, tapak liman, kamandrah dan pulai. Penelitian dilakukan dengan percobaan yang menggunakan rancangan acak kelompok dengan lima ulangan. Perlakuan yang diberikan meliputi ekstrak empat macam tumbuhan rawa dan ditambah dengan 3 perlakuan kontrol, yaitu kontrol 1 (tanpa pengendalian), kontrol 2 (perlakuan insektisida nabati BGA) dan kontrol 3 (insektisida kimiawi Dimehipo). Dari hasil penelitian dapat disimpulkan bahwa tumbuhan-tumbuhan jingah, tapak liman, simpur dan tumbuhan kamandrah efektif dalam mengendalikan hama utama padi di lahan rawa pasang surut. Hasil gabah kering panen dengan aplikasi ekstrak tumbuhan rawa adalah sebesar 4,54-4,62 t/ha dan kontrol insektisida kimia 4,63 t/ha, insektisida nabati BGA. Untuk kenyamanan bagi penggunakan maka ekstrak tumbuhan jingah perlu dipertimbangkan karena ekstrak tumbuhan jingah ini dapat menimbulkan alergi dan gatal-gatal kalau terkena kulit dan sangat mengganggu bagi pengguna.

Kata kunci: hama padi, insektisida nabati, rawa pasang surut 


\section{PENDAHULUAN}

Dalam upaya peningkatan produksi tanaman pangan untuk dapat memenuhi kebutuhan pangan dalam negeri maupun ekspor maka strategi peningkatan produksi tanaman pangan dapat dilakukan melalui: a) pengembangan sarana dan prasarana; b) akselerasi peningkatan produktivitas; c) kegiatan perluasan areal tanam; d) pengamanan produksi; serta e) pengelolaan dan pemasaran hasil (Rusdiana dan Maesya, 2017).

Pengelolaan hama tanaman dalam sistem produksi pertanian di lahan rawa pasang surut merupakan salah satu bagian penting dalam mening-katkan produktivitas. Hama tanaman merupakan resiko yang harus dihadapi dan diperhitungkan dalam budidaya tanaman untuk meningkatkan produksi sesuai dengan harapan. Resiko ini adalah konsekuensi dari perubahan ekosistem sebagai akibat budidaya tanaman yang dilakukan, sedangkan ketidaktentuan iklim adalah hal yang harus diterima sebagai fenomena alam. Peranan perlindungan tanaman dalam sistem produksi terus berkembang seiring dengan perkembangan teknologi. Oleh sebab itu, diperlukan teknologi inovatif untuk pengelolaan hama tanaman, khususnya di lahan rawa pasang surut (Susanti et al., 2016).

Dalam pengendalian hama dan penyakit pada para petani umumnya cenderung menggunakan pestisida/insektisida kimiawi, karena hasilnya cepat dilihat dan mudah didapatkan serta murah cara penggunaannya. Untung (2004) melaporkan bahwa pada pengendalian hama terpadu, penggunaan bahan kimia beracun atau pestisida/insektisida kimiawi merupakan alternatif terakhir. Apabila upaya-upaya lainnya tidak mampu mengendalikan hama lagi, baru pestisida/ insektisida dapat digunakan. Bahkan sekarang ini mulai dikembangkan pestisida/insektisida nabati dalam mengendalikan hama tanaman. Hal ini karena penggunaan pestisida/insektisida kimiawi yang kurang bijaksana dan terus-menerus akan menimbulkan masalah pencemaran lingkungan yang berakibat terjadinya ledakan hama, terjadinya resistensi dan resurgensi hama, terbunuhnya hama bukan sasaran, terbunuhnya musuh alami hama tanaman dan pengerahuruh buruk bagi konsumen dan hewan peliharaan.

Adapun alternatif pengendaliannya diarahkan kepada pemanfaatkan bahan tumbuhan/tanaman sebagai pestisida/insektisida nabati. Pada lahan rawa ditemukan sangat beragam jenis tumbuhan/tanaman yang berpotensi sebagai bahan obat-obatan dan insektisida nabati. Di lahan rawa ditemukan sekitar $350-500$ jenis tumbuhan/tanaman yang berpotensi sebagai insektisida nabati, dari jumlah tersebut sekitar 90-100 jenis tumbuhan rawa berpotensi sebagai bahan pembuatan insektisida nabati dalam mengendalikan hama padi, hama sayuran/hortikultura. Adapun jenis tumbuhan tersebut beberapa di antaranya adalah tanaman jingah, tapak liman, dembung dan kamandrah.

Penelitian ini bertujuam untuk mendapatkan jenis tumbuhan rawa yang efektif dalam mengendalikan hama utama padi di lahan rawa pasang surut.

\section{METODE PENELITIAN}

Penelitian ini di laksanakan di Desa Sidomulyo, Kecamatan Tamban Catur, Kabupaten Kuala Kapuas, Provinsi Kalimantan Tengah pada musim tanam 2018/2019. Bahan dan alat yang digunakan meliputi bahan tanaman sebagai sumber insektisida yaitu tumbuhan jingah, tapak liman, simpur dan kamandrah. Insektisida kimiawi Dimehipo (PT. Kenso Indonesia) dan insektisida nabati BGA digunakan sebagai kontrol. Alat yang digunakan adalah pisau, parang, tikat, kantungan, tali rafia, ember dan alat pepanas/penguap water bath.

Penelitian dilakuan dengan percobaan yang menggunakan rancangan acak kelompok dengan lima ulangan. Perlakuan yang diberikan meliputi ekstrak 4 macam tumbuhan rawa dan ditambah dengan 3 perlakuan kontrol, yaitu kontrol 1 (tanpa pengendalian), kontrol 2 (perlakuan insektisida nabati BGA) dan kontrol 3 (insektisida kimiawi 'Dimehipo') (Tabel 1).

Varietas padi yang digunakan Inpara 2 yang ditanam dalam petak perlakuan berukuran masingmasing 0,25 ha dengan jarak tanam $20 \mathrm{~cm} \times 20 \mathrm{~cm}$ secara jajar legowo (1:2). Takaran pupuk yang digunakan untuk setiap hektarnya sebanyak $90 \mathrm{~kg} \mathrm{~N}, 45 \mathrm{~kg} \mathrm{P_{2 }} \mathrm{O}_{5}$ dan $45 \mathrm{~kg}$ $\mathrm{K}_{2} \mathrm{O}$. Pupuk diberikan pada saat tanam, kecuali $\mathrm{N}$ hanya diberikan setengahnya, sisanya diberikan pada saat tanaman berumur 30 hari setelah tanam. Pemberian kapur akan dilakukan 15 hari sebelum tanam dengan takaran $1000 \mathrm{~kg} / \mathrm{ha}$. Waktu aplikasi perlakuan dilaksanakan berdasarkan tingkat kerusakan tanaman. Pengamatan dilakukan terhadap populasi dan jenis hama serangga, intensitas kerusakannya, musuh alami (parasitoid dan predator), serta hasil padi.

Pengamatan juga dilakukan terhadap persentase hama pemakan daun padi (hama putih (Nymphula depunctalis), hama putih palsu (Cnaphalocrosis medinalis) dan belalang (Orthoptera), hama penggerek batang padi putih (Scirpophaga innotata) pada saat tanaman berumur 25,58 , dan 75 hari setelah tanam dan hasil panen (gabah kering panen).

Untuk menghitung persentasi intensitas serangan hama penggerek batang padi digunakan rumus sebagai berikut (Leatemia dan Rumthe, 2011):

$$
M=\frac{a}{b} \times 100 \%
$$

Keterangan: $\mathbf{M}=$ intensitas serangan; $a=$ jumlah anakan terserang/mati; $b=$ jumlah batang tanaman.

Penilaian intensitas kerusakan serangan hama pada daun dilakukan dengan rumus:

$$
P=\frac{\sum\left(n_{i} \times v_{i}\right)}{Z \times N} \times 100 \%
$$

Dimana: $P=$ intensitas serangan yang menyebabkan kerusakan bervariasi; $n_{i}=$ banyaknya daun dari katagori serangan ke- $i ; v_{i}=$ nilai skala dari daun tanaman terserang yang diamati dari katagori serangan ke- $i ; \mathrm{N}=$ banyaknya daun tanaman yang diamati; dan $\mathrm{Z}=$ nilai skala dari kategori serangan yang ditetapkan tertinggi. 
Tabel 1. Perlakuan insektisida nabati tumbuhan rawa dalam mengendalikan hama utama padi di Desa Sidomulyo, Tamban Catur di lahan rawa pasang surut pada musim tanam 2019

\begin{tabular}{llcc}
\hline No. & Jenis Tumbuhan Sebagai Perlakuan & Bagian Tanaman & Keterangan \\
\hline 1. & Jingah (Glutha rengas) & daun & pohon \\
2. & Tapak Liman (Elephantopus scaber L) & daun & daun \\
3. & Simpur (Dellinia indica) & daun & pohon \\
4. & Kamandrah $($ Croton tiglium) & - & Air \\
5. & Kontrol 1 Tanpa Pengendalian & - & BGA \\
6. & Kontrol 2 Insektisida Nabati/BGA & - & Dimehipo \\
7. & Kontrol 3 Insektisida kimia/Dimehipo & & \\
\hline
\end{tabular}

Pembuatan ekstrak padat pestisida nabati dilakukan dengan cara merendam masing-masing bahan tumbuhan segar ke dalam masing-masing pelarut (etanol dan aseton) dengan perbandinngan setiap $1000 \mathrm{~g}$ bahan tumbuhan dicampur 2-3 L pelarut (Asikin, 2006). Setelah direndam selama 24 jam, campuran bahan dengan pelarut tersebut disaring dan hasil saringan dievaporasi dengan vacum untuk menghasilkan residu, kemudian dimasukkan ke dalam cawan terbuka dan dipanaskan pada waterbath dengan suhu $40^{\circ} \mathrm{C}$. Untuk membentuk ekstrak padat maka pemanasan harus dilakukan selama lebih kurang 48 jam. Sebelum aplikasi perlakuan, terlebih dahulu ekstrak padat dicampur dengan Tween 80 dengan perbandingan 10:1 agar daya rekatnya pada tanaman lebih kuat dan penyebarannya merata pada permukaan tanaman. Mencampur ekstrak padat dengan Tween dilakukan pada pelat kaca hingga merata kemudian dimasukkan ke dalam gelas dan dicampur dengan air sebanyak $1 \mathrm{~L}$ per $2 \mathrm{~g}$ ekstrak padat, dan selanjutnya ekstrak siap untuk disemprotkan ke tanaman.

\section{HASIL DAN PEMBAHASAN}

\section{Serangan Hama Pemakan Daun}

Jenis hama yang menyerang pertanaman padi di daerah rawa pasang surut di Desa Sidomulyo antara lain adalah hama pemakan daun (hama putih, hama putih palsu dan belalang) dan untuk penggerek batang padi yang meliputi hama penggerek batang padi putih (Scirphoga innotata) dan untuk lahan rawa lebak hama penggerek batang padi kuning (Scirphoga incertulas).

Pada pengamatan pertama, pada yaitu 25 hari setelah tanam (hst), secara uji statistik menunjukkan tidak ada perbedaan antar perlakuan ekstrak tumbuhan rawa deangan kontrol insektisida nabati nimba dan kontrol tanpa pengendalian (Tabel 2). Hal ini karena pada saat itu reaksi dari ekstrak tumbuhan rawa masih belum bekerja dengan baik atau reaksinya lambat. Menurut Asikin dan Thamrin (2009) dan Mutiah et al. (2013), reaksi insektisida nabati relatif lambat dibandingkan dengan insektisida kimiawi, dimana semua perlakuan ekstrak tumbuhan rawa tidak berbeda dengan kontrol insektisida kimiawi maupun insektisida nabati BGA (Tabel 2).

Pada pengamatan kedua, yaitu pada 50 hst, terjadi peningkatan persentase intensitas serangan hama perusak daun yang secara uji statistik menunjukkan perbedaan yang sangat nyata antar perlakuan. Perlakuan ekstrak tumbuhan rawa tidak berbeda nyata terhadap kontrol insektisida kimiawi Dimehipo dan insektisida nabati BGA. Pada pengamatan kedua ini sudah terlihat reaksi hama terhadap perlakuan ekstrak tumbuhan rawa/insektisida nabati rawa. Walaupun intensitas serangan meningkat tetapi reaksi dengan adanya perlakuan ekstrak tumbuhan rawa juga terjadi sehingga serangan hama perusak daun tersebut dapat ditekan.

Pada pengatan selanjutnya, yaitu 75 hst, juga terjadi peningkatan persentase intensitas serangan hama pemakan daun sebagaimana yang ditunjukkan oleh uji statistik, yaitu terdapat perbedaan intensitas serangan yang nyata antara kontrol tanpa pengendalian terhadap perlakuan-perlakuan dengan ekstrak tumbuhan rawa (Tabel 2). Tidak terdapat perbedaan di antara ekstrak tumbuhan rawa dan kontrol insektisida kimiawi, tetapi terdapat perbedaan yang nyata dengan kontrol tanpa pengendalian dan kontrol insektisida nabati BGA. Persentase instensitas serangan pada perlakuan ekstrak tumbuhan rawa berkisar antara 6,89-7,68\%, sedangkan pada kontrol insektisida nabati BGA $(14,16 \%)$ dan kontrol insektisida kimiawi Dimehipo 5,19\%. Intensitas serangan pada kontrol tanpa perlakuan adalah yang tertinggi, yaitu $34,98 \%$.

Rendahnya intensitas kerusakan daun pada perlakuan ekstrak tumbuhan rawa disebabkan oleh adanya kandungan bahan aktif atau volatel-volatel yang bekerja sehingga kemungkinan dapat mempengaruhi tingkah laku dari hama pemakan daun tersebut.

\section{Serangan Hama Penggerek Batang Padi}

Jenis hama penggerek batang padi yang ditemukan dominan menyerang pertanaman padi di lahan rawa pasang surut adalah penggerek batang padi putih dan yang menyerang pertanaman padi di lahan rawa lebak adalah penggerek batang padi kuning. Pada pengamatan pertama yang dilakukan pada 25 hst, uji statistik menunjukkan adanya perbedaan yang nyata antar perlakuan terhadap serangan hama penggerek batang padi. Perlakuan ekstrak tumbuhan rawa tidak berbeda dengan kontrol insektisida kimiawi, tetapi berbeda nyata dengan kontrol tanpa pengendalian (Tabel 3). 
Tabel 2. Ekstrak tumbuhan rawa terhadap persentase intensitas serangan hama pemakan daun di Desa Sidomulyo, Tamban Catur di lahan rawa pasang surut pada musim tanam 2019

\begin{tabular}{llccc}
\hline \multirow{2}{*}{ No. } & \multicolumn{2}{c}{ Jenis Tumbuhan/Perlakuan } & \multicolumn{3}{c}{ Pengamatan (\%)/HST } \\
\cline { 3 - 5 } & Jingah (Glutha rengas) & $4,45 \mathrm{~b}$ & $5,77 \mathrm{~b}$ & $6,89 \mathrm{c}$ \\
\hline 1. & $3,96 \mathrm{~b}$ & $4,43 \mathrm{~b}$ & $6,92 \mathrm{c}$ \\
2. & Tapak Liman (Elephantopus scaber L) & $4,23 \mathrm{~b}$ & $5,35 \mathrm{~b}$ & $7,68 \mathrm{c}$ \\
3. & Simpur (Dellinia indica) & $4.15 \mathrm{~b}$ & $5,53 \mathrm{~b}$ & $7,17 \mathrm{c}$ \\
4. & Kamandrah (Croton tiglium) & $4,11 \mathrm{~b}$ & $18,79 \mathrm{a}$ & $34,98 \mathrm{a}$ \\
5. & Kontrol 1 Tanpa Pengendalian & $5,74 \mathrm{~b}$ & $6,14 \mathrm{~b}$ & $14,16 \mathrm{~b}$ \\
6. & Kontrol 2 Insektisida Nabati/BGA & $1,15 \mathrm{a}$ & $3,86 \mathrm{~b}$ & $5,19 \mathrm{c}$ \\
7. & Kontrol 3 Insektisida kimia/Dimehipo & &
\end{tabular}

Keterangan: Angka yang diikuti oleh huruf yang sama pada baris yang sama tidak berbeda nyata menurut uji DMRT pada taraf $95 \%$.

Tabel 3. Ekstrak tumbuhan rawa terhadap persentase intensitas serangan hama penggerek batang padi Desa Sidomulyo, Tamban Catur di lahan rawa pasang surut pada musim tanam 2019

\begin{tabular}{llccc}
\hline \multirow{2}{*}{ No. } & \multicolumn{2}{c}{ Jenis Tumbuhan/Perlakuan } & $25 \mathrm{hst}$ & Pengamatan $(\%)$ \\
\cline { 3 - 5 } & & $1,00 \mathrm{~b}$ & $2,83 \mathrm{~b}$ & $75 \mathrm{hst}$ \\
\hline 1. & Jingah (Glutha rengas) & $0,66 \mathrm{~b}$ & $2,25 \mathrm{~b}$ & $6,42 \mathrm{~b}$ \\
2. & Tapak Liman (Elephantopus scaber L) & $1,00 \mathrm{~b}$ & $2,67 \mathrm{~b}$ & $6,97 \mathrm{~b}$ \\
3. & Simpur (Dellinia indica) & $1,08 \mathrm{~b}$ & $2,35 \mathrm{~b}$ & $5,36 \mathrm{~b}$ \\
4. & Kamandrah (Croton tiglium) & $5,83 \mathrm{a}$ & $12,08 \mathrm{a}$ & $18,35 \mathrm{a}$ \\
4. & Kontrol 1 Tanpa Pengendalian & $1,34 \mathrm{~b}$ & $4,67 \mathrm{~b}$ & $7,86 \mathrm{~b}$ \\
5. & Kontrol 2 Insektisida Nabati/BGA & $0,76 \mathrm{~b}$ & $1,96 \mathrm{~b}$ & $5,37 \mathrm{~b}$ \\
6. & Kontrol 3 Insektisida kimia/Dimehipo & &
\end{tabular}

Keterangan: Angka yang diikuti oleh huruf yang sama pada baris yang sama tidak berbeda nyata menurut uji DMRT pada taraf $95 \%$.

Rata-rata intensitas serangan hama penggerek batang padi pada perlakuan-perlakuan ekstrak tumbuhan rawa berkisar antara $0,66-1,08 \%$, pada insektisida kimiawi $0,76 \%$, dan pada kontrol insektisida nabati BGA $1,34 \%$; sedangkan pada kontrol tanpa pengendalian adalah $5,83 \%$.

Pada pengamatan selanjutnya yaitu pada 50 dan 75 hst, saat reaksi ekstrak tumbuhan rawa sudah lancar maka ekstrak-ekstrak tersebut dapat menekan serangan hama penggerek batang padi.

Kandungan dari ekstrak tumbuh-tumbuhan rawa sebagai pestisida nabati adalah sebagaimana uraian berikut. Tumbuhan jingah memiliki getah dan sangat beracun, dan dapat menyebabkan iritasi berat pada kulit dan dapat melumpuhkan manusia. Berdasarkan laporan, tumbuhan ini belum banyak diteliti. Pada penelitian sebelumnya,vgetah rengas dilaporkan mengandung senyawa ursiol, rengol, glutarengol, laccol dan thitsiol. Hasil penelitian kayu rengas dilaporkan mengandung senyawa golongan steroid, lipid, benzenoid dan flavonoid, sedangkan kandungan pada akar, buah, bunga, kulit batang dan lain-lain pada tumbuhan ini belum banyak dilaporkan. Meskipun efektivitas senyawa kimia nabati jauh di bawah senyawa kimia sentitik, tetapi senyawa tersebut mempunyai kelebihan, yaitu kurang menimbulkan dampak negatif dari risidu yang terjadi melalui rantai makanan yang membahayakan manusia dan lingkungan. Menurut Asikin dan Thamrin (2002), tanaman jingah ini cukup efektif dalam mengendalikan hama penggerek batang padi, yaitu mencapai $83,65 \%$.
Menurut Tampungan et al. (2011), senyawasenyawa metabolit sekunder yang terkandung pada tumbuhan perlu dilakukan uji toksisitas/daya racun untuk mengetahui efek toksiknya dari senyawa-senyawa yang dihasilkan. Dalam melakukan uji daya racun suatu senyawa bisa menggunakan metode Brine Shrimp Lethality Test (BSLT), dimana makhluk hidup yang biasa digunakan adalah Artemia salina yang merupakan udang primitif yang termasuk dalam Filum Arthropoda. Frengki et al. (2014) melaporkan bahwa suatu pengujian tentang toksisitas pada suatu produk dalam rangka pencarian produk alam yang potensial yang biasanya menggunakan makhluk hidup sebagai sampel.

Rumouw (2017) melaporkan bahwa kandungan kimia tumbuhan tapak liman (famili Asteraceae) meliputi alkaloid, flavonoid, fenolik, saponin dan tanin. Hasil penelitian menunjukkan bahwa ekstrak daun tapak liman dapat menekan serang hama pemakan daun padi sebesar $6,92 \%$. Rendahnya intensitas kerusakan daun padi pada perlakuan ekstrak daun tapak liman adalah karena daun tapak liman mengandung senyawa antifeedan, sehingga menyebabkan tanaman terhindar dari serangan hama pemakan daun. Daun tapak liman banyak mengandung senyawa kimia, yaitu saponin dan flavanoid (Asmaliyah et al., 2010). Menurut Harborne (1996) tanaman ini juga terkandung minyak atsiri (Amin et al., 2019); saponin merupakan racun kontak dan racun perut. Saponin dapat mengurangi daya makan dan menyebabkan lisis sel. Flavonoid berfungsi menghambat pertumbuhan larva (Karimah, 2006; Kurniawan, 2011). Redha (2010) dan Siahaya dan Rumthe (2014) juga menyatakan bahwa 
senyawa flavanoid berfungsi sebagai antifeedan, sehingga berpengaruh terhadap aktivitas makan hama. Berdasarkan hasil penelitian yang telah dilakukan, ekstrak etanol daun simpur juga mengandung alkaloid, fenol, tanin,flavonoid, steroid, terpenoid, dan saponin. Minyak atsiri berfungsi sebagai anti hormon juvenil. Pestisida nabati ekstrak tapak liman juga telah diteliti oleh Asikin (2013), sebagai biopestida terhadap hama ulat grayak.

Iswantini et al. (2007) melaporkan bahwa tanaman kamandrah merupakan tanaman obat yang banyak ditemukan di lahan rawa daerah Kalimantan; berdasarkan kearifan lokal masyarakatnya banyak menggunakan bijinya untuk membunuh jentik-jentik nyamuk, sedangkan batang dan daunnya dibakar untuk mengusir nyamuk. Thamrin et al. (2007) melaporkan bahwa ekstrak biji kamandrah cukup ampuh membunuh jentik nyamuk $A$. aegypti hingga $84 \%$ dengan LD50 sebesar $0,06 \%$. Senyawa 12-0-tetradecanoylphorbol-13acetate (TPA) hasil isolasi dari $C$. tiglium dapat membunuh $100 \%$ larva Culex pipiens instar 2 pada konsentrasi 0,6 ppm (Marshall dan Kinghorn, 1984).

Identifikasi komponen minyak kamandrah dengan GC-MS mendapatkan bahwa senyawa (Z)-13octadecenal dan cis-9-hexadecenal berfungsi sebagai feromon, serta piperine merupakan suatu golongan alkaloid sejenis piperidin yang diduga sebagai larvasida/insektisida (Iswantini et al., 2007). Senyawa golongan piperidine dapat membunuh nyamuk $A$. aegypti dan yang menunjukkan aktivitas sebagai larvasida adalah 2-ethyl-piperidine (Pridgeon et al., 2007) dan pipernonaline ekstrak Piper longum. Penggunaan konsentrasi minyak kamandrah $0,3-0,5 \%$ dapat menghambat penetasan telur (ovisida) dan menurunkan jumlah peletakan telur pada ovitrap (anti-oviposisi) nyamuk $A$. aegypty dan A. albopictus (Iswantini et al., 2007; Astuti, 2008).

Menurut Iswantini et al. (2007) dan Roufiq (2012), bahwa tanaman dari genus Croton memiliki bioaktivitas anti hipertensi, anti inflamasi, anti malaria, anti mikroba, dan anti virus. Penelitian mengenai potensi tinggi dari tanaman kamandrah sebagai larvasida ini sudah dilakukan. Dari hasil pengujian diketahui bahwa ekstrak biji kamandah cukup ampuh membunuh jentik dan telur nyamuk Aedes aegypti hingga 84\% dengan tingkat kematian 50\% larva nyamuk dengan 0,06\% bahan, dan tingkat kematian 50\% tikus sebesar 9,11 $\mathrm{mg} / \mathrm{tikus}$. Akan tetapi, ekstrak ini dapat menyebabkan iritasi kulit manusia dan menimbulkan sakit perut pada hewan mamalia. Walaupun ekstrak biji kamandrah ini bermanfaat besar dan efektif sebagai larvasida hayati Aedes aegypti karena hanya memerlukan konsentrasi yang sangat rendah, tetapi karena berdampak tidak baik terhadap manusia dan hewan, maka sangat perlu untuk meneliti potensi bagian lain tumbuhan ini sebagai larvasida, seperti batang dan daun yang sudah biasa digunakan sebagai obat nyamuk oleh masyarakat Kalimantan.

Menurut Duke (1983), ekstrak tumbuhan kumandrah memiliki bahan kimia yang meliputi phorbol 13-decanoate, juga phorbol ester lainnya yaitu 4deoxy$4 \alpha$-phorbol diester. Phorbol monoester (Marshal dan Kinghorn, 1984), senyawa phorbol ester yang ditemukan paling tinggi konsentrasinya adalah phorbol 12 tiglate 13-decanote dan terdapat bentuk minyak kroton yang efektif dalam penggunaan sebagai pestisida. Senyawa ini mempunyai sifat lebih efektif daripada ekstrak Derris yang merupakan insektisida, dan bersifat aktif sebagai moluskisida terhadap sejenis keong kecil Oncomelania quadrasi (Mashaguchi et al., 1977).

Kandungan pada tumbuhan kumandrah dapat mematikan nimpa wereng coklat, yang dapat mencapai $100 \%$. Karena kandungan bahan aktif pada tumbuhan kumandrah tersebut bersifat racun bagi serangga hama. Indonesia terkenal kaya akan keanekaragaman hayati, termasuk jenis tumbuhan yang mengandung bahan aktif insektisida. Tanama kamandrah merupakan salah satu tanaman obat bagi masyarakat yang terdapat di Indonesia dan telah dimanfaatkan sebagai bahan insektisida nabati.

Penelitian mereka bertujuan untuk mengetahui karakteristik pengaruh fisiko-kimia minyak kamandrah pada berbagai tingkat kematangan sebagai larvasida nabati terhadap larva nyamuk demam berdarah dengue (A. aegypti).

Tabel 4. Hasil gabah kering (t/ha)

\begin{tabular}{llc}
\hline No. & \multicolumn{1}{c}{ Perlakuan Ekstrak } & Hasil (ton/ha) \\
\hline 1. & Jingah (Glotha rengas) & $4,54 \mathrm{a}$ \\
2. & Tapak Liman (Elephantopus scaber L) & $4,60 \mathrm{a}$ \\
3. & Simpur (Dellinia indica) & $4,57 \mathrm{a}$ \\
4. & Kamandrah (Croton tiglium) & $4,62 \mathrm{a}$ \\
5. & Kontrol 1 Tanpa Pengendalian & $2,12 \mathrm{~b}$ \\
6. & Kontrol 2 Insektisida Nabati/BGA & $4,32 \mathrm{a}$ \\
7. & Kontrol 3 Insektisida kimia/Dimehipo & $4,63 \mathrm{a}$ \\
\hline
\end{tabular}

Keterangan: Angka yang diikuti oleh huruf yang sama pada kolom yang sama tidak berbeda nyata menurut uji DMRT pada taraf $95 \%$. 


\section{Hasil Gabah Kering Panen}

Untuk hasil gabah kering panen (t/ha) dari penelitian ini, uji statistik menunjukkan perbedaan yang nyata dimana semua ekstrak tumbuhan rawa tidak berbeda nyata dengan perlakuan insektisida kimiawi dan sangat berbeda nyata dengan perlakuan kontrol tanpa pengendalian. Hasil gabah kering panen pada dari tanaman yang diberi perlakuan ekstrak tumbuhan rawa adalah 4,54-4,62 t/ha dan kontrol insektisida kimia 4,63 t/ha, insektisida nabati BGA 4,32 t/ha (Tabel 4).

\section{KESIMPULAN}

Dari hasil penelitian dapat disimpulkan bahwa ekstrak tumbuh-tumbuhan jingah, tapak liman, simpur dan kamandrah efektif sebagai insektisida nabati dalam mengendalikan hama utama padi di lahan rawa pasang surut. Hasil panen gabah dengan penggunaan ekstrak tumbuh-tumbuhan tersebut setara dengan pada penggunaan insektisida nabati BGA dan insektisida kimia Dimehipo. Untuk kenyamanan bagi penggunakan maka ekstrak tumbuhan jingah perlu dipertimbangkan karena ekstrak tumbuhan ini menyebabkan sangat gatal jika terkena kulit dan sangat menggangu bagi pengguna.

\section{DAFTAR PUSTAKA}

Amin, M., P.M.J. Taihuttu, dan U. Lestari. 2019. Bioaktif alami dari minyak atsiri akar wangi terhadap pengaruh kerusakan lambung. Jurnal Bioterdidik 7: 64-68.

Asikin, S. dan M. Thamrin. 2009. Tumbuhan Rawa Sebagai Insektisida Nabati. Kegiatan HamaPenyakit Balai Penelitian Pertanian Lahan Rawa. $7 \mathrm{p}$.

Asikin, S. 2013. Ekstrak tapak liman (Elephantopus scaber L.) sebagai biopestida terhadap hama ulat grayak. Banjar Baru: Balai Penelitan Pertanian Lahan Rawa (Balittra). http://balittra.litbang.pertanian.go.id/index.php/c omponent/content/article/25publikasi/prosiding/1326-ekstrak-tumbuhantapak-liman-elephantopus-scaber-1-sebagaibiopestisida-terhadap-hama-ulat-grayak. Diakses April 2020.

Asikin, S. 2006. Pembuatan Insektisida Nabati Rawa. Laporan Kegiatan Hama-Penyakit Tumbuhan. Balai Penelitian Pertanian Lahan Rawa. 5p.

Asikin, S. dan M. Thamrin. 2002. Bahan Tumbuhan Sebagai Pengendali Hama Ramah Lingkungan. Disampai pada Seminar Nasional Lahan Kering dan Lahan Rawa 18-19 Desember 2002. BPTP Kalimantan Selatan dan Balittra. Banjarbaru.

Asmaliyah, Etik Erna Wati H., S. Utami, K. Mulyadi, Yudhistira, F.W. Sar. 2010. Pengenalan Tumbuhan Penghasil Pestisida Nabati dan Pemanfaatannya Secara Tradisional. Palembang: Badan Penelitian dan Pengembangan Kehutanan.
Astuti, E.P. 2008. Efektivitas Minyak Biji Jarak Pagar (Jatropha curcas) Sebagai Larvasida, Antioviposisi dan Avicidal Nyamuk Aedes aegypti dan Aedes albipictus. Tesis. Sekolah Pasca Sarjana Institut Pertanian Bogor, Bogor. 70p.

Duke, J.A. 1983. Purging croton, Physic-nut, Croton-oil plant. Handbook of Energy Crops. http://www.hort.purdue.edu/newcrop/duke_energ y/Croton_tiglium.html, diakses April 2020.

Frengki, R. dan P. Pertiwi. 2014. Uji toksisitas ekstrak etanol sarang semut lokal Aceh (Mymercodia $s p$ ) dengan metode BSLT terhadap larva udang Artemia salina Leach. Jurnal Medika Veterinaria 8: 60-62.

Harborne, J.B. 1996. Metode Fitokimia: Penentuan Cara Modern Menganalisa Tumbuhan. Terjemahan K. Padmawinata dan I. Soediro. Bandung: ITB.

Iswantini, D., R. Rosman, D. Mangunwidjaja, U.K. Hadi, dan M. Rahminiwat. 2007. Bioprospeksi Tanaman Obat Kamandrah (Croton tiglium L.): Studi Agrobiofisik dan Pemanfaatannya Sebagai Larvasida Hayati Pencegah Demam Berdarah Dengue. Laporan Hasil Penelitian KKP3T: Institut Pertanian Bogor bekerjasama dengan Badan Penelitian dan Pengembangan Pertanian Jakarta

Karimah, L.N. 2006. Uji Aktivitas Larvasida Ekstrak Etanol 96\% Biji Mahoni (Swietenia mahagoni Jacq.) terhadap Larva Nyamuk Anopheles aconitus Instar III serta Profil Kromatografi Lapis Tipis. Universitas Muhammadiyah Surakarta: Fakultas Farmasi.

Kurniawan, O. 2011. Pengaruh Pemberian Hormon Tiroksin (T4) Dengan Perendaman Terhadap Pertumbuhan dan Kelulushidupan Benih Ikan Gurami (Osphronemus gouramy Lac). Jurusan Budidaya Perairan, Fakultas Pertanian. Universitas Riau. p. 40-48.

Leatemia, J.A. dan R.Y. Rumthe. 2011. Studi kerusakan akibat serangan hama pada tanaman pangan di Kecamatan Bula, Kabupaten Seram Bagian Timur, Propinsi Maluku. Jurnal Agroforestri 6: 52-56.

Marshall, G.T. and A.D. Kinghorn. 1984. Short-chain phorbol ester constituents of croton oil. Journal of the American Oil Chemists Society 61: 12201225. DOI: $10.1007 / \mathrm{BF} 02636256$.

Mashaguchi, J., K. Yasuraoka, H. Tanaka, A.T. Santos, and B.L. Bias. 1977. Molluscicidal activity of the seed of tu ba croton tiglium againstoncemelania quadras. Jap. Journal Parasitology 26: 37-38.

Mutiah, S., L. Lubis, dan Y. Pangestiningsih. 2013. Uji efektivitas beberapa insektisida nabati untuk mengendalikan ulat grayak (Spodoptera litura F.) (Lepidoptera: Noctuidae) di laboratorium. Jurnal Online Agroekoteknologi 1: 560-569.

Pridgeon, Y.W., K.M. Meepagala, J.J. Becnel, G.C. Gary, M.P. Roberto, and J.L. Kenneth. 2007. Structure-activity relationships of 33 piperidines as Toxicants against female adults of Aedes 
aegypti (Diptera: Culicidae). Journal of Medical Entomology 44: 263-269. doi.org/10.1093/jmedent/44.2.263.

Redha, A. 2010. Flavonoid: struktur, sifat antioksidatif dan peranannya dalam sistem biologis. Jurnal Belian 9: 196-202.

Roufiq, N. 2012. Rekayasa Proses Ekstraksi Minyak Biji Kamandrah (Croton tiglium L) Dengan Pengempaan dan Pengembangannya Sebagai Larvasida Nabati Pencegah Penyakit Demam. Disertasi. Institut Pertanian Bogor, Bogor.

Rumouw, D. 2017. Identifikasi dan analisis kandungan fitokimia tumbuhan alam berkhasiat obat yang dimanfaatkan masyarakat sekitar kawasan hutan lindung Sahedaruman. Jurnal LPPM Bidang Sains dan Teknologi 4: 53-66.

Rusdiana. S dan A. Maesya. 2017. Pertumbuhan ekonomi dan kebutuhan pangan di Indonesia. Jurnal Agriekonomika 6: 12-25.

Siahaya, V.G. dan R.Y. Rumthe. 2014. Uji ekstrak daun pepaya (Carica papaya) terhadap larva Plutella xylostella (Lepidoptera: Plutellidae). Agrologia 3: 112-116. DOI: 10.30598/a.v3i2.251.

Susanti, M.A., M. Thamrin, dan S. Asikin. 2016. Hama Serangga Utama Padi di Lahan Rawa Pasang Surut. Prosiding Seminar Nasional Lahan Basah Tahun 2016, Jilid 1: 170-179.

Tampungan, W.A., I.E. Herny, S. Herny, E. de Queljoe, dan S. Wulur. 2011. Uji toksisitas ekstrak batang pinang Yaki (Areca vestiaria) pada Artemiasalina Leach. Jurnal Bioslogos 1: 8-12. DOI: 10.35799/jbl.1.1.2011.370.

Thamrin, M., S. Asikin, Mukhlis, dan A. Budiman. 2007. Potensi ekstrak flora lahan rawa sebagai pestisida nabati. Laporan Hasil Penelitian Balittra, pp.3554. Penelitian Pertanian Lahan Rawa.

Untung, K. 2004. Dampak pengendalian hama terpadu terhadap pendaftaran dan penggunaan pestisida di Indonesia. Jurnal Perlindungan Tanaman Indonesia 10: 1-7. 